\title{
TTR
}

Traduction, terminologie, re?daction

\section{In memoriam Georges Mounin (1910-1993)}

\section{Claude Tatilon}

Volume 6, numéro 1, 1er semestre 1993

\section{L'Histoire en traduction}

URI : https://id.erudit.org/iderudit/037134ar

DOI : https://doi.org/10.7202/037134ar

Aller au sommaire du numéro

\section{Éditeur(s)}

Association canadienne de traductologie

\section{ISSN}

0835-8443 (imprimé)

1708-2188 (numérique)

Découvrir la revue

\section{Citer ce document}

Tatilon, C. (1993). In memoriam Georges Mounin (1910-1993). TTR, 6(1), 7-7.

https://doi.org/10.7202/037134ar d'utilisation que vous pouvez consulter en ligne.

https://apropos.erudit.org/fr/usagers/politique-dutilisation/ 


\section{En hommage dे Georges Mounin}

\section{In memoriam Georges Mounin (1910 -1993)}

Une fois encore, le monde de la traduction est en deuil; Georges Mounin nous a quittés le 10 janvier dernier.

Son grand ouvrage, les Problèmes théoriques de la traduction, paru il y a trente ans, continuera de longues années encore à nourrir la réflexion par l'étendue de ses connaissances, la rigueur de ses analyses et la profondeur de ses vues. Georges Mounin est également l'auteur des Belles Infidèles (1955), où il traite avec une remarquable finesse de la traduction littéraire, ainsi que de nombreux articles dont quelques-uns sont repris dans Linguistique et traduction (1976).

Théoricien de la traduction, mais aussi traducteur et critique de poésie, linguiste, stylisticien, sémiologue, Georges Mounin avait des intérêts extrêmement divers, dont témoigne éloquemment une très volumineuse bibliographie.

Homme érudit, généreux, sensible, sa perte paraîtra énorme à tous ceux qui l'ont bien connu. Mais ses écrits nous restent, et son chaleureux souvenir.

Claude Tatilon

Université York 